\title{
Pedagógusok, iskola, bizalom - EGY MOZGALMAS ÉVTIZED VÁLTOZÁSAI
}

\author{
SZÉLL KRISZTIÁN ${ }^{a, \star}$ - FEHÉRVÁRI ANIKÓ ${ }^{a, b}-$ PAKSI BORBÁLA ${ }^{a, c}$ \\ ${ }^{a}$ ELTE PPK Neveléstudományi Intézet \\ ${ }^{\mathrm{b}} \mathrm{OFI}$ \\ ${ }^{\mathrm{c}}$ Viselkedéskutató $\mathrm{Kft}$.
}

Tanulmányunk három pedagógus-adatfelvétel $(2004,2009,2014)$ alapján arra keresi a választ, hogy 2004 és 2014 között miként alakult a pedagógusok által észlelt szervezeti bizalom az iskolákban, az adatfelvételi évek (mint időtényezők) magyarázzák-e a gyakorló pedagógusok bizalmi szintjét, illetve, hogy mely tényezők befolyásolják jelentősen a pedagógusok szervezeti bizalommal kapcsolatos személyes percepcióit. A lineáris regressziós modelleken alapuló eredményeink azt jelzik, hogy a vizsgált 10 éves időszak változásai nem írhatók le lineáris folyamatként: 2004-hez képest 2009-ben bizalomnövekedés, ezt követően 2014-ben viszont jelentős bizalomcsökkenés következett be. Hozzátéve, hogy 2014-ben az egyéni jellemzők helyett már egyértelmüen a formális (regionális elhelyezkedés, fenntartó) és informális jellemzook (tantestületen belüli légkör) gyakoroltak jelentős hatást a pedagógusok szervezeti bizalommal kapcsolatos percepcióira.

Kulcsszavak: szervezeti bizalom, iskolai légkör, longitudinális pedagógusvizsgálat, lineáris regressziós modell

Based on three rounds of teacher survey $(2004,2009,2014)$, our study aims to explore how organisational trust in schools as perceived by teachers changed between 2004 and 2014, whether the years of conducting the surveys (as time factors) explain teachers' levels of trust and that what factors influence significantly the individual perceptions of teachers regarding organisational trust. Our results based on linear regression models indicate that changes in the ten years under scrutiny cannot be described as a linear process: compared to 2004, there was an increase of trust in 2009 but following that, a significant decline of trust occurred in 2014. Furthermore, in 2014, instead of individual characteristics, it was formal (regional location, maintainer) and informal (school climate) factors that exerted a significant influence on teachers' perceptions regarding organisational trust.

Keywords: organizational trust, school climate, longitudinal study of teachers, linear regression model

* Levelező szerző: Széll Krisztián, ELTE PPK, Neveléstudományi Intézet, 1075 Budapest, Kazinczy u. 23-27. E-mail: szell.krisztian@ppk.elte.hu 


\section{Bevezetés}

A z iskolában folyó oktató-nevelő munka alapvető kötőszövete a szervezetben megjelenő bizalom, amely irányulhat vezetőre, kollégákra, szervezeti működésre, szakmaiságra egyaránt. Hozzátéve, hogy a bizalom egyfajta kölcsönös viszonyt feltételez (bizalmat adó - bizalmat kapó), nem véletlen, hogy a bizalomra több szerző is úgy tekint, hogy nélküle nem alakulhat ki együttmüködő szervezeti kultúra (HarrisCaldwell-Longmuir 2013; Hargreaves-Fullan 2012).

Ugyanakkor egy néhány éve végzett pedagóguskutatás szerint a hazai iskolákat erős versengés és jelentős bizalomhiány jellemzi, mely nem csupán a toxikusként érzékelt szervezetek sajátja, hanem sokkal általánosabb jelenségnek tekinthető, s olyan szervezeti kultúrában is megjelenhet, amelyben egyébként a közös tanulás vagy a befogadó, családias szellemiség a mérvadó. A kutatás fontos eredménye, hogy a bizalom hiányát sok esetben nem érzik problémának a pedagógusok, és azt sem feltétlenül gondolják, hogy a minőségi, eredményes szakmai munkához feltétlenül bizalmi alapon szerveződő közösségre lenne szükség. Ennek egyik fö oka, hogy a kutatásban részt vevő pedagógusok gondolkodásában a bizalom, az együttmüködés és a közösség fogalmai főként a személyes szférához tartozóként jelennek meg, ezen fogalmak szakmai, professzionális vonatkozású értelmezése kevésbé elterjedt (Kopp 2016).

Mindezekből kiindulva tanulmányunk három, közoktatási intézményekben tanító fóállású pedagógusokra irányuló adatfelvétel $(2004,2009,2014)$ alapján arra keresi a választ, hogy 1. 2004 és 2014 között miként alakult a pedagógusok által észlelt szervezeti bizalom az iskolákban; 2. hogy az adatfelvételi évek (mint időtényezők) magyarázzák-e, és ha igen, milyen mértékben a gyakorló pedagógusok vezetők, munkatársak iránti, illetve a szervezet müködésével, szakmaiságával kapcsolatos bizalom szintjét; valamint hogy 3. mely tényezők befolyásolják jelentősen a pedagógusok szervezeti bizalommal kapcsolatos személyes percepcióit, vannak-e olyan tényezők, amelyek hatása mindhárom évben megmutatkozik.

\section{A bizalom szerepe a szervezetekben}

Jelen tanulmány a szervezeti bizalmat olyan, „a szervezeti tagok által osztott hitnek tekinti, mely az egyén átélt vagy észlelt szervezeti tapasztalatainak interpretációja nyomán alakul, és a szervezet mint részekből álló rendszer megbízhatóságára vonatkozó pozitív (vagy negatív) elvárásokat foglal magában, melyeknek kognitív és érzelmi összetevőik vannak. A szervezeti bizalom megnyilvánul a szervezettel kapcsolatos egyéni viszonyulásban (kognitív, érzelmi összetevőkkel), valamint az ebből következő személyes vagy személyközi bizalomadó viselkedésben." (Sass 2005: 15.)

Az eddigi kutatások egyértelműen igazolják, hogy a bizalommal teli tanár-diák kapcsolatok, az iskolaközösség tagjai közötti megértő és építő kommunikáció és az ebből keletkező társadalmi, szociális, kapcsolati és kulturális tőkeelőnyök erős hatást gyakorolnak a tanulmányi eredményességre, a tanulók sikeres előrehaladására (Coleman 1988; Bourdieu 1997; Bryk-Schneider 2002; Hargreaves-Fullan 2012). Korábbi hazai kutatások is megerősítették, hogy a bizalommal teli iskolai légkör meghatározó szerepet játszik a pedagógusok lelki egészségének alakulásában, köztük a kiégés elkerülésében (Paksi- 
Schmidt 2006; Paksi et al. 2015), továbbá összefügg a pedagógusok pályamotivációival, pályán maradásával, illetve a pályaelhagyás kockázatával is (Paksi et al. 2015).

A szervezeti bizalom kapcsán kiemelendő továbbá, hogy a támogató szakmai közösség - a tanári együttműködések, a tudásmegosztás, a pedagógiai gyakorlatok széles körű terjesztése, valamint a közös tevékenységből eredő erős elköteleződés révén - az egyéni szinthez képest olyan kollektív, hozzáadott értéket jelent, ami mind egyéni, mind kollektív szinten teljesítménynövekedést eredményez (Fullan 2010, 2011). Hargreaves és Fullan (2012) tőkeelmélet koncepciójukban szintén a kollektív felelősség és elszámoltathatóság mellett érvelnek, s kiemelik, hogy az oktatás mint kollektív vállalkozás a pozitív és szakszerü együttmüködések révén növeli a tanulói teljesítményeket és a tanári professzionalizmust is. Koncepciójukban központi szerepet kap a bizalom is, mely a szociális tőke hordozója, s egyfajta garanciaként jelenhet meg a szervezetek optimális müködését segítő szabályok és viselkedési normák betartására. Bryk és munkatársai is hangsúlyozzák a bizalmi hálók iskolafejlesztések eredményességében betöltött jelentős szerepét (Bryk et al. 2010). A kapcsolati bizalom egyfajta összekötő szövetként koordinálja és támogatja az iskolafejlesztések eredményességét befolyásoló négy, egymásra ható dimenzió - a szakmai kapacitások; a tanulási környezet (rend, biztonság, normák); a szülők, iskola és közösség kapcsolatrendszere és a tanítási iránymutatások (például összehangolt tantervek) - müködését.

\section{Elemzési keret: adatok és módszerek}

Elemzésünk fókuszában a pedagógusok szervezeti bizalommal kapcsolatos személyes percepciói állnak. A szervezeti bizalom mérésére a Sass-féle Szervezeti Bizalom Skálát (Sass 2005) alkalmaztuk. A mérőeszköz kilenc alskála mentén vizsgálja I. a vezetővel kapcsolatosan, II. a munkatársak közötti kapcsolatokban, III. a szervezet müködésében, illetve IV+az intézményen belüli szakmaiság vonatkozásában a pedagógusok által percipiált bizalmi szintet:

I. Vezetőre irányuló bizalom:

1. Igazságos, beosztottakat bevonó vezető: egyéni beleszólást lehetővé tevő, személyes célokat figyelembe vevő vezetői hozzáállás, vezetői támogatás, igazságos bánásmód.

II. Munkatársakra irányuló bizalom:

2. Kölcsönös munkatársi törödés: a munkatársi kapcsolatok szakmai és ezen belül érzelmi, kapcsolati oldalára, a munkavégzés felelösségteljes, elkötelezett voltára és a munkakapcsolatok önzetlen segítő, a másik problémáira odafigyelő jellegére utaló tartalmi kategóriák (a szervezeti tagok számíthatnak a másik felelős, színvonalas munkavégzésére és önzetlen segítségére a munkában).

3. Munkatársi visszaélés hiánya: a munkatársi kapcsolatban, munkavégzésben, illetve érzelmi-kapcsolati szinten a megbízhatóságra, jóindulatra, azaz a kihasználás, visszaélés, negatív szándék hiányára utaló tartalmak (bizalmas közlés lehetősége, megbízható munkavégzés, kihasználás veszélyének hiánya).

4. Munkatársi munkamorál kétsége (magas értéke bizalmatlanságot jelöl): munkatársak munkavégzésével kapcsolatos megbízhatóságának a kétsége, vagyis ellenőrizni, 
figyelni kell a másik munkavégzését, hiányzik a „szavahihetőség”, ami nehezíti a kooperációt, óvatosságot von maga után.

III. Szervezeti működésre irányuló bizalom:

5. Integritás a szervezeti müködésben: elfogadott szabályoknak megfelelő müködés, valamint a bizalommal való visszaélés hiánya (a bizalomadó által is elfogadott elvek szerinti működés).

6. Kontroll eredményezte kiszámithatóság: szervezeti működés szabályozottságának magas szintjére utal (kiszámíthatóság, stabilitás, világos elvárások felmutatása).

7. Merev szabálybetartatás (magas értéke bizalmatlanságot jelöl): bizalomhiányra utaló merev szabálybetartatással jellemezhető szervezeti működés, mely a szervezet tagjainak érdekeit nem veszi figyelembe (a kontroll eredményezte kiszámíthatóságtól a szabályozás mértékbeli eltérésének jelentősége különbözteti meg).

8. Önfeltárás akadályozottsága (magas értéke bizalmatlanságot jelöl): a szervezet menynyire teszi lehetővé tagjai számára gyengeségeik, bizonytalanságuk vállalását, mennyire élnek vissza az ilyen önfeltáró információval (ahol magas az önfeltárás akadályozottsága, ott hiányzik a magas szintű érzelmi alapú bizalom, vagy nem néz szembe a szervezet a bizalmatlansággal).

IV. Szakmaiságra irányuló bizalom:

9. Szakmai kompetenciaorientáltság: szervezeti tagok szakmai fejlődésének, önkiteljesítésének lehetősége.

Jelen elemzésben a pedagógusok által észlelt szervezeti bizalom különböző alskálái mentén mért átlagértékek 2004 és 2014 közötti alakulását, illetve az egyes alskálák értékét (mint függő / eredmény / cél változókat) meghatározó tényezőket vizsgáltuk lineáris regressziós modellek segítségével. Elemzéseink során egy évtizedet átölelő, 2004-ben, 2009-ben, és 2014-ben, a közoktatási intézményekben tanító főállású pedagógusok országos reprezentatív mintáján készült, az adatfelvétel és a jelen elemzés során felhasznált kérdések tekintetében azonos módszereket alkalmazó három kutatás eredményeit használtuk (az adatfelvételek föbb módszertani jellemzöit lásd az 1. mellékletben).

Kutatási kérdéseinknek megfelelően elemzésünk két részből áll. Először a három vizsgálati év egyesített adatbázisán azt elemeztük, hogy az adatfelvételek évei (2004, 2009, 2014) - mely adatfelvételi évek koncepciónk szerint eltérő társadalmi és egyben oktatáspolitikai kontextust testesítenek meg - a pedagógusok egyéni jellemzőinek, illetve iskolájuk formális és informális szervezeti jellemzőinek kontroll alatt tartása mellett magyarázzák-e, és ha igen, milyen mértékben a gyakorló pedagógusok bizalmi szintjét. A szervezeti bizalom mind a kilenc alskálájára a feltáró vizsgálatok során alkalmazható Stepwise módszerrel építettünk egy-egy lineáris regressziós modellt, melyek mindegyikébe az adatfelvételi éveket mutató dummy változókon túl további 35 egyéni (nem, pályán eltöltött idő, mióta dolgozik jelenlegi iskolájában, iskolában ellátott feladatok, milyen képzési típusokban tanít), illetve formális (tantestület mérete, egy pedagógusra jutó tanulók száma, régió, településtípus, fenntartó) és informális szervezeti jellemzőt 
(tantestületen belüli légkör iskolai szintre aggregált átlagértékei ${ }^{1}$ ) megjelenítő magyarázó változót vontunk be (a magyarázó változók listáját a 2. melléklet tartalmazza). ${ }^{2}$

Ezt követően azt is megvizsgáltuk, hogy az eltérő években megvalósuló adatfelvételek során mely egyéni, illetve mely formális és informális szervezeti jellemzők befolyásolják jelentősen a pedagógusok szervezeti bizalomra vonatkozó percepcióit. A szervezeti bizalom kilenc alskálájának becslésére mindhárom adatfelvételi évben külön-külön, lineáris regressziós modelleket alkottunk, így összesen 27 modellt építettünk. Mivel alapvetően arra voltunk kíváncsiak, hogy a három adatfelvételi évben milyen egyezőségek, illetve különbségek tárhatók fel, ezért az elemzést a megerősítő elemzések esetében alkalmazható Enter módszerrel végeztük. ${ }^{3}$ A független (magyarázó) változókat mindegyik modell esetében ugyanaz a 31 elemü, egyéni és szervezeti szintű jellemzőket is tartalmazó komplex változószett képezte (a változószett leirását a 2. melléklet tartalmaz$z a)$, mely abban különbözik a korábbiakban tárgyalt kilenc modell esetében alkalmazott 38 elemű változószettől, hogy értelemszerűen nem tartalmazza az adatfelvételi éveket, továbbá a tantestületen belüli légkört egy ( 0 átlagú és 1 szórású) főkomponens elemzéssel létrehozott index ${ }^{4}$ segítségével ragadja meg. Utóbbi adatredukciós eljárásra az Enter módszerrel futtatott modellek során tapasztalt multikollinearitás elkerülése érdekében volt szükség.

Fontos kiemelni elemzésünk korlátait is. Elemzésünk során a három adatfelvétel közös metszetét jelentő adatokat használtuk, ami mind a bevonható változók, mind a minta nagysága tekintetében korlátot szabott vizsgálódásainknak.

\section{A szervezeti bizalom elemeivel kapcsolatos pedagógusi percepciók változása (2004-2014)}

$\mathrm{A} z$ adatfelvételi évek dummy változóit tartalmazó regressziós modellek eredményeinek bemutatása előtt érdemes megvizsgálni a modell függő változóinak, azaz a pedagógusok 9 alskálával mért bizalmi szintjének a 2004-2014-es időszak közötti alakulását.

A z alskálák között valamennyi vizsgált évben szignifikáns összefüggés tapasztalható, ${ }^{5}$ s különösen szoros kapcsolat mutatható $\mathrm{ki}^{6}$ a vezetőre irányuló Igazságos, beosztottakat

1 Csak abban az esetben számoltunk feladatellátási helyekre aggregált átlagértékeket, ha az adott feladatellátási helyről legalább két pedagógus válaszolt a kérdéssorra.

2 A modellek mindegyike szignifikáns $(p<0,001)$, homoszkedasztikus, egyik esetben sem mutatható ki nagyon erős, káros multikollinearitás (VIF-mutató < 3), valamint az autokorreláció is elfogadhatóan alacsony (Durbin-Watson-mutató értékei 1,7 és 1,8 közé esnek).

3 A modellek mindegyike szignifikáns $(p<0,001$, a merev szabálybetartás esetén: $p<0,05)$, homoszkedasztikus, egyik esetben sem mutatható ki nagyon erős, káros multikollinearitás (VIF-mutató < 5), valamint az autokorreláció is elfogadhatóan alacsony (Durbin-Watson-mutató értékei 1,7 és 2,1 közé esnek).

4 A főkomponens a tantestületi légkör dimenzióit öt tulajdonságpár (feszült - oldott, kevéssé innovatív szellemű - haladó szellemű, kicsinyes - nagyvonalú, merev - rugalmas, visszahúzó - ösztönző) segítségével jellemző, iskolai szintre aggregált változók által megtestesített információ (heterogenitás) $72 \%$-át őrzi meg. Az indexkialakítás megbízhatóságát Cronbach-alfa értékekkel teszteltük, mely alapján a fökomponens megbízhatónak bizonyult $(0,899)$. A fókomponens-elemzéssel létrehozott index nagyobb értéke kedvezőbb (oldottabb, haladó szellemübb, nagyvonalúbb, rugalmasabb, ösztönzőbb) tantestületi légkört fejez ki.

5 Pearson-féle korreláció: $p<0,001$.

6 A Pearson-féle korrelációs együttható értékei minden vizsgált évben 0,65-0,75 között alakulnak. 
bevonó vezetö, a Kölcsönös munkatársi törödés, a Munkatársi visszaélés hiánya, az Integritás a szervezeti müködésben és a Szakmai kompetenciaorientáltság alskálák között. Ez egybecseng Handford és Leitbwood (2013) kutatási eredményeivel, akik azt találták, hogy az iskolákban dolgozó pedagógusok közötti bizalom szoros összefüggésben áll a vezetőbe vetett bizalommal. Eredményeik szerint a szervezeti bizalmi légkört erősíti a kompetencia, a következetesség és megbízhatóság, a nyitott gondolkodásmód, a tisztelet és az integritás.

$\mathrm{A} z$ adatok alapján összességében kijelenthető, hogy a pedagógusok mindhárom évben az iskolájukban észlelt szakmai kompetenciaorientáltságot értékelték átlagosan a legmagasabbra. Ezt a szervezet müködésének kontroll eredményezte kiszámíthatósága, a kölcsönös munkatársi törődés, az iskolavezető iránti, illetve a munkatársi visszaélés hiányát jelző bizalmi komponensek követték. A közoktatási intézményekben tanító fóállású pedagógusok szerint a bizalom hiányára utaló dimenziók közül az iskola merev szabálybetartása sokkal inkább jellemző, mint a nem megfelelő munkatársi munkamorál vagy az önfeltárást akadályozó magas szintű érzelmi alapú bizalom hiánya. Az egyes évek összevetése kapcsán kiemelendő, hogy a vizsgált évtizedben kizárólag a munkatársi munkamorál kétségét jelző alskála esetében nem tapasztalható szignifikáns változás. A másik két fordított - azaz a nagyobb átlagértékkel nagyobb bizalmatlanságot mutató - alskála (Merev szabálybetartatás, Önfeltárás akadályozottsága) esetében az Unióhoz való csatlakozásunk évében, 2004-ben voltak a legkedvezőbbek az átlagértékek, azonban azóta az ezeken a területeken mért bizalmatlanság emelkedett, állandósult. A vizsgált évtized félidejében történt, 2009-es adatfelvétel során a szervezeti bizalom legtöbb komponense esetén a bizalmi szint szignifikánsan meghaladja a kiinduló, 2004-es adatfelvételi évben tapasztaltakat. Vagyis a nagyobb bizalomra utaló alskálák 2004 és 2009 között javuló tendenciát mutatnak, illetve egy, a szervezeti integritást jelző alskála átlagértéke statisztikai értelemben nem jelez változást. 2009 után viszont egyértelmü, szignifikáns visszaesés tapasztalható, azaz a javulás átmenetinek bizonyult, a bizalmi szint visszaállt a 2004-es szintre, sőt az elfogadott szabályoknak megfelelő müködést mutató szervezeti integritás kapcsán 2004-hez képest is jelentős csökkenés következett be a nagy oktatáspolitikai beavatkozások után, 2014-ben (1. táblázat).

A szervezeti bizalom kilenc komponensére vonatkozó pedagóguspercepciók variabilitásának magyarázatára létrehozott, a három adatfelvételi évet együtt vizsgáló lineáris modellek - melyekben az adatfelvétel évei is mint magyarázó változók szerepelnek mindegyike szignifikáns, ugyanakkor a modellek magyarázó ereje széles skálán mozog. A bizalmatlanságot kifejező (fordított) alskálák magyarázatára igen gyenge modelleket sikerült létrehozni: a Munkatársi munkamorál kétsége, a Merev szabálybetartatás és az Önfeltárás akadályozottsága alskálák magyarázó ereje nem éri el, de a Kontroll eredményezte kiszámíthatóság alskáláé is csak alig haladja meg a 10\%-ot. Vagyis a szervezeti bizalom ezen komponensei a rendelkezésre álló független változókkal csak igen kismértékben magyarázhatók, a modelleredmények megkérdőjelezhetők vagy legalábbis erős fenntartásokkal kezelendők (Hunyadi 2000). A szervezeti bizalom 5 elemét viszont közepesen erős (20\% feletti) lineáris modellekkel sikerült magyarázni. A modellek alapján összességében az alábbi megállapítások tehetők (2. táblázat):

- Az adatfelvételek éve az individuális és szervezeti jellemzőket megjelenítő magyarázó változók kontroll alatt tartása mellett szignifikánsan befolyásolja azt, hogy a pedagógusok miként észlelik iskolájukban a szervezeti bizalom egyes elemeit. 2004 és 2009 
- SZÉLL KRISZTIÁN - FEHÉRVÁRI ANIKÓ - PAKSI BORBÁLA: PEDAGÓGUSOK, ISKOLA, BIZALOM -

1. táblázat: Az egyénileg észlelt szervezeti bizalom alskáláinak átlagértékei 2004-ben, 2009-ben és 2014-ben ${ }^{+}$

\begin{tabular}{|c|c|c|c|c|c|c|c|c|c|}
\hline & \multicolumn{3}{|c|}{2004} & \multicolumn{3}{|c|}{2009} & \multicolumn{3}{|c|}{2014} \\
\hline & $N$ & Átlag & Szórás & $N$ & Átlag & Szórás & $N$ & Átlag & Szórás \\
\hline \multicolumn{10}{|l|}{ Vezető } \\
\hline $\begin{array}{l}\text { Igazságos, beosztotta- } \\
\text { kat bevonó vezetö }\end{array}$ & 982 & 5,0 & 1,17 & 675 & 5,3 & 1,03 & 825 & 4,9 & 1,18 \\
\hline \multicolumn{10}{|l|}{ MunKatÁrsak } \\
\hline $\begin{array}{l}\text { Kölcsönös munka- } \\
\text { társi törődés* }\end{array}$ & 957 & 5,0 & 0,99 & 661 & 5,3 & 0,89 & 826 & 5,1 & 0,97 \\
\hline $\begin{array}{l}\text { Munkatársi visszaélés } \\
\text { hiánya* }^{*}\end{array}$ & 995 & 4,8 & 1,27 & 674 & 5,0 & 1,21 & 831 & 4,8 & 1,23 \\
\hline $\begin{array}{l}\text { Munkatársi munka- } \\
\text { morál kétsége }\end{array}$ & 980 & 3,1 & 1,31 & 674 & 3,2 & 1,33 & 823 & 3,2 & 1,34 \\
\hline \multicolumn{10}{|l|}{ SZERVEZETI MŰKÖDÉS } \\
\hline $\begin{array}{l}\text { Integritás a szervezeti } \\
\text { működésben* }\end{array}$ & 968 & 5,1 & 1,16 & 667 & 5,0 & 1,13 & 825 & 4,7 & 1,28 \\
\hline $\begin{array}{l}\text { Kontroll eredményez- } \\
\text { te kiszámíthatóság* }\end{array}$ & 973 & 5,2 & 1,13 & 671 & 5,5 & 0,95 & 828 & 5,3 & 1,12 \\
\hline $\begin{array}{l}\text { Merev szabály- } \\
\text { betartatás* }\end{array}$ & 983 & 4,5 & 0,99 & 674 & 4,9 & 1,00 & 829 & 4,7 & 1,04 \\
\hline $\begin{array}{l}\text { Önfeltárás akadályo- } \\
\text { zottsága* }\end{array}$ & 998 & 2,8 & 1,27 & 682 & 3,1 & 1,36 & 841 & 3,0 & 1,39 \\
\hline \multicolumn{10}{|l|}{ Szakmaiság } \\
\hline $\begin{array}{l}\text { Szakmai kompetencia- } \\
\text { orientáltság* }\end{array}$ & 984 & 5,5 & 0,99 & 678 & 5,7 & 0,85 & 828 & 5,4 & 1,02 \\
\hline
\end{tabular}

${ }^{+}$A tételek mérése 7 fokozatú skálán történt. ${ }^{*}$ NNOVA: $p<0,001$. A táblázatban vastagítva jelöltük azon adatfelvételi évek átlagértékeit, amelyek a Bonferroni post hoc teszt alapján szignifikánsan eltérnek a másik két adatfelvételi év átlagértékeitől. A táblázatban dőlten jelzett alskálák fordított skálák, melyek esetében a magasabb értékek nagyobb bizalmatlanságot jelölnek.

között az időtényező szinte mindegyik alskála estében szignifikánsan növelte az átlagértékeket, míg 2004 és 2014 között több elem esetében (munkamorál, szervezeti integritás, önfeltárás lehetőségei) szignifikáns bizalomcsökkenést okozott.

- A pedagógusok iskolájuk mint szervezet iránt érzett bizalmát leginkább a tantestületi légkör egyes elemei határozzák meg. Itt elsősorban az oldottabb, illetve ösztönzőbb légkördimenziókat kell kiemelnünk, melyek a szervezeti bizalom szinte minden elemére jelentős mértékben kedvező hatást gyakorolnak, azaz növelik a bizalmat, illetve csökkentik a bizalmatlanságot. Ugyanakkor a légkör két másik dimenziója némiképp más tendenciákat tár elénk. Az eredmények szerint minél haladóbb szellemü, innovatívabb egy tantestület, a pedagógusok percepcióiban annál kevésbé van jelen a szervezeti integritás, a szervezeti múködés inkább a merev szabálybetartatás felé 


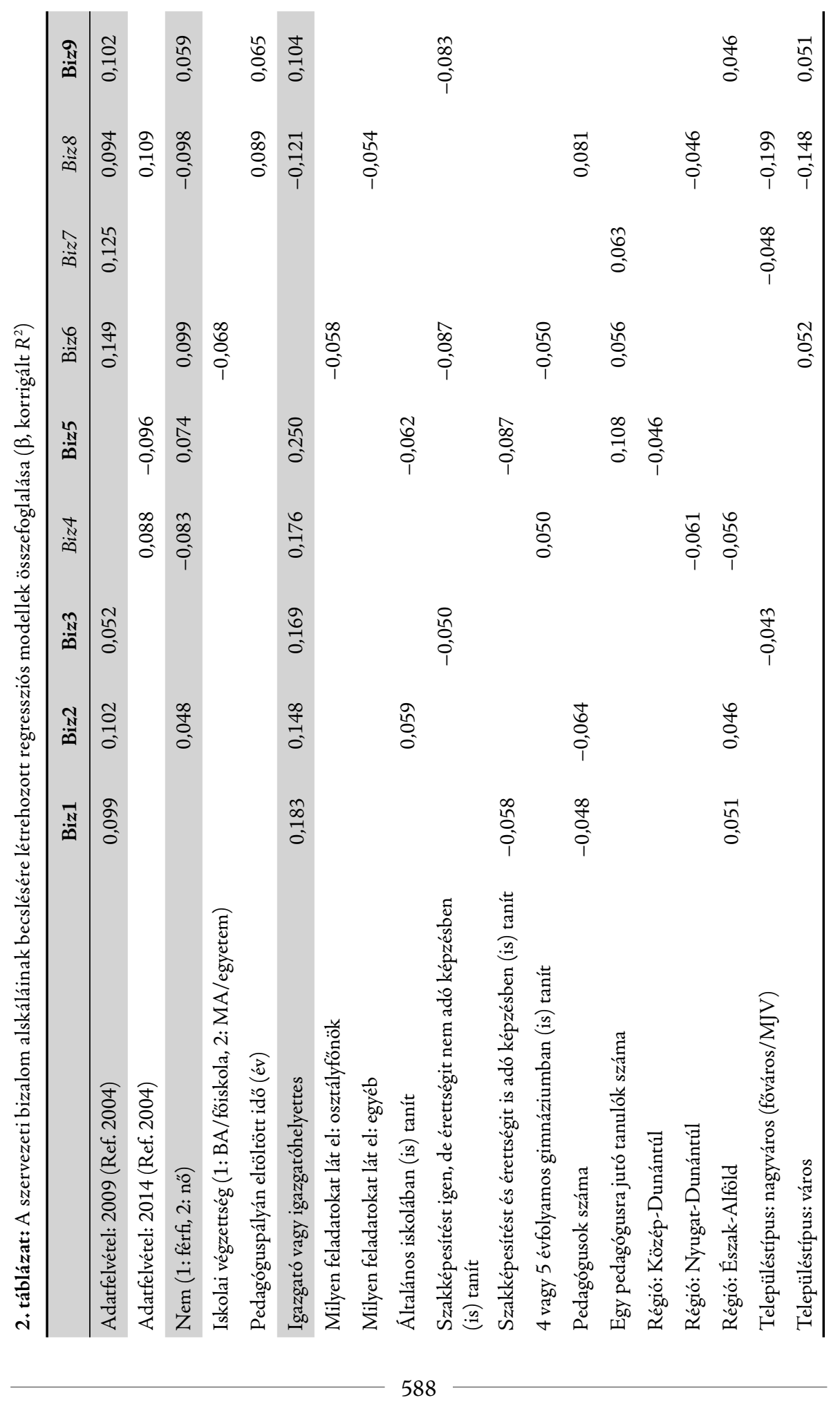




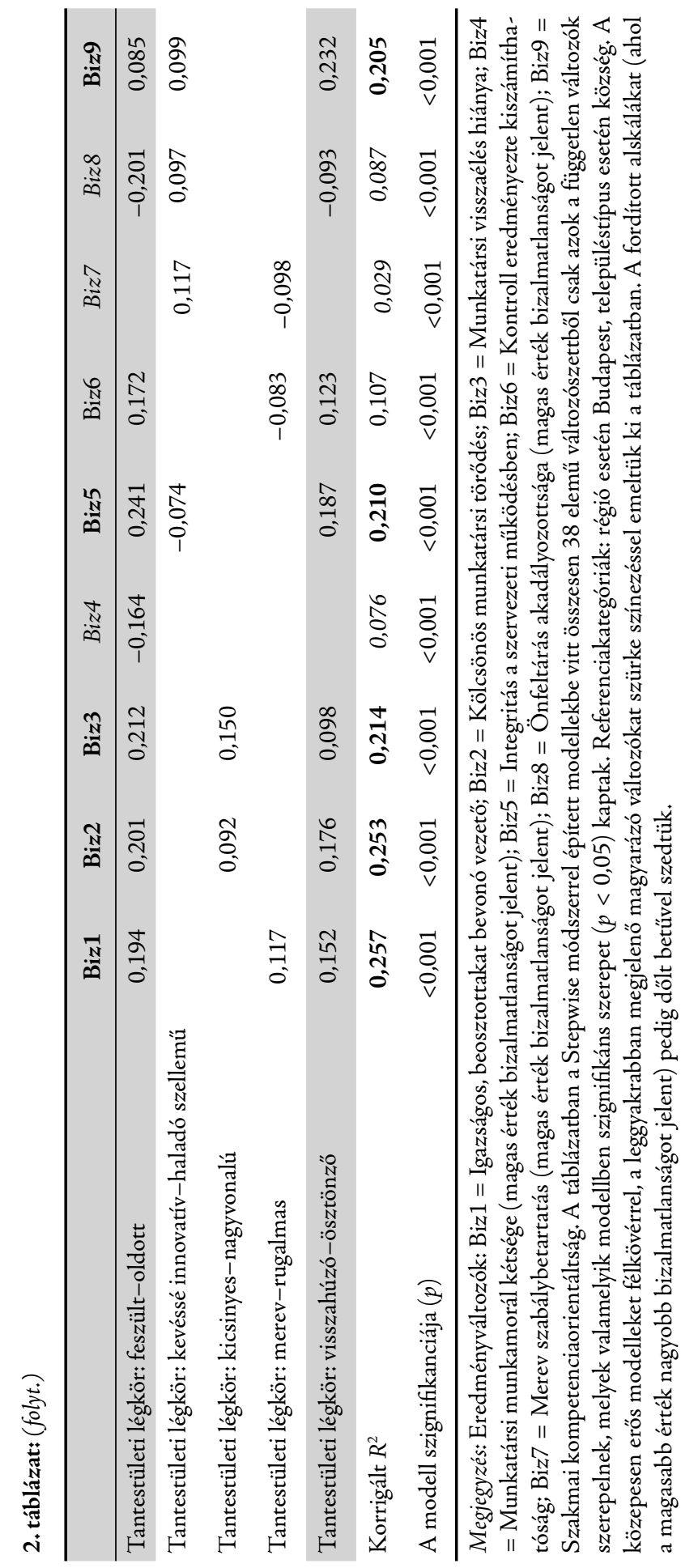


mozdul el, mellyel párhuzamosan a bizonytalanság vállalása, az önfeltárás lehetősége is korlátozottabb, a szakmaiság megítélése viszont erősebb. Ez arra utalhat, hogy az újszerü, innovatív megoldások sok esetben a korábbiakhoz képest más, olykor merevebb struktúrával járnak együtt annak érdekében, hogy maga az innováció megvalósulhasson. A rugalmasabb tantestületi légkör amellett, hogy erősíti a vezetőről alkotott igazságos, beosztottakat bevonó képet, értelemszerűen csökkenti a bármiféle kontrollhoz - akár a szervezeti stabilitást biztosító mértékü kontrollról, akár merev szabálybetartásról legyen is szó - kapcsolható értékeket.

- A szervezeti bizalom több alskálája esetében a nemnek is szignifikáns szerep jut: a nők pedagóguskollégák iránt érzett bizalma, illetve a szervezet megfelelő működésével, szakmaiságával kapcsolatos percepciói szignifikánsan kedvezőbbek, mint a férfiaké.

- Szerepükből adódóan az iskolavezetés tagjainak szervezettel kapcsolatos bizalomérzete is szignifikánsan magasabb más munkatársakénál. Ugyanakkor egy tényező, a munkatársi morál megítélésében kisebb bizalom tapasztalható esetükben, mely vélhetően szintén a vezetői szerepkör sajátosságainak tudható be.

- A fenti magyarázó változókon kívül az Igazságos, beosztottakat bevonó vezetö (korrigált $\left.R^{2}=0,257\right)$ alskála értékét csökkenti a szakközépiskolában (szakgimnáziumban) folytatott oktatói tevékenység és a tantestület méretének emelkedése, viszont a fóvárosi iskolákhoz képest növeli az, ha az adott iskola az Észak-Alföld régióban működik. A Kölcsönös munkatársi törödés (korrigált $R^{2}=0,253$ ) esetén szintén a magasabb pedagógusszám okoz negatív hatást, az Észak-Alföld régió és az általános iskolai képzésben való szerepvállalás azonban pozitívan befolyásolja a komponens értékét. A Munkatársi visszaélés hiánya (korrigált $R^{2}=0,214$ ) a községi iskolákhoz képest alacsonyabb a nagyvárosi iskolákban, illetve a szakképzésben is tanítók esetében is. A Munkatársi munkamorál kétsége (korrigált $R^{2}=0,076$ ) erősebben jelenik meg a gimnáziumokban is tanítók körében, ugyanakkor a Nyugat-Dunántúlon és az Észak-Alföldön működő iskolában a fővárosi iskolákhoz képest kedvezőbb ezen dimenzió megítélése. Azok a pedagógusok, akik a Közép-Dunántúl régióban, illetve általános iskolában vagy szakközépiskolában (szakgimnáziumban) is tanítanak, kevésbé érzékelik a szervezeti bizalom Integritás a szervezeti müködésben (korrigált $\left.R^{2}=0,210\right)$ elemét, az egy pedagógusra jutó tanulólétszám emelkedése azonban kedvezőbbé teszi az integritással kapcsolatos pedagóguspercepciót. A Kontroll eredményezte kiszámithatóság (korrigált $R^{2}=0,107$ ) érzése a városi iskolákban, illetve azon iskolákban magasabb, ahol nagyobb az egy pedagógusra jutó tanulók száma, viszont alacsonyabb a magasabb iskolai végzettségűek, az osztályfönökök, illetve a szakképzésben vagy gimnáziumban is tanítók körében. A szervezeti múködés kontrollja által eredményezett kiszámíthatósághoz hasonlóan a Merev szabálybetartatás (korrigált $R^{2}=0,029$ ) ott magasabb, ahol nagyobb az egy pedagógusra jutó tanulók száma, viszont ez a fajta túlzott merevség a nagyvárosi iskolákra kevésbé jellemző. $\mathrm{A} z$ Önfeltárás akadályozottsága (korrigált $R^{2}=0,087$ ) erősebb akkor, ha több éve van a pedagógus a pályán, és ha nagyobb a tantestület létszáma, ugyanakkor az akadályozottság érzetét csökkenti az egyéb feladatok ellátása, valamint az iskola városi, nagyvárosi környezete, illetve nyugat-dunántúli elhelyezkedése. A Szakmai kompetenciaorientáltság (korrigált $R^{2}=0,205$ ) dimenziójára a pályán eltöltött évek száma, az iskola észak-alföldi elhelyezkedése, illetve városi környezete hat pozitívan, míg a szakképzésben (is) folytatott oktatói tevékenység negatív hatást mutat. 


\section{A szervezeti bizalom elemeivel kapcsolatos személyes percepciók évenkénti vizsgálata}

A pedagógusok iskola mint szervezet iránt érzett bizalmát, illetve annak elemeit meghatározó tényezők évenkénti elemzéséből általánosságban megállapítható, hogy a pedagógusok egyéni jellemzőit, valamint formális és informális szervezeti jellemzőket egyaránt tartalmazó komplex modellek a szervezeti bizalom valamennyi alskálája esetén lényegesen nagyobb magyarázóerővel bírnak, mint a csak individuális jellemzők mentén vizsgálódó modellek. ${ }^{7}$ Továbbá az is megfigyelhető, hogy a 2004-es és a 2009-es adatfelvételekre épülő komplex modellekben még számos individuális jellemző is szignifikáns szerepet kap, a legutolsó vizsgált évben (2014) azonban már szinte kizárólag a formális és informális szervezeti jellemzők dominálnak.

A fentiekben vázolt tendenciák jól tetten érhetők a vezető iránt érzett bizalom magyarázatában. A 2004-es adatok alapján épített lineáris modellben annak megítélésében, hogy mennyire igazságos, munkatársakat bevonó az iskola vezetője még jelentős pozitív szerepet kaptak olyan egyéni jellemzők, mint a pályán eltöltött évek száma, valamint az, hogy a válaszoló az iskolavezetés tagja-e (igazgató, igazgatóhelyettes), másképp fogalmazva, hogy a saját szerepét ítélte-e meg. Az egyéni jellemzők mellett a formális szervezeti jellemzők közül a tantestület méretének emelkedése, illetve az iskola fövároshoz képesti közép-dunántúli elhelyezkedése szignifikánsan csökkentette, a kedvezőbb tantestületi légkör - mint informális szervezeti jellemző - viszont nagymértékben növelte a vezető iránti bizalom értékét. 2009-re az igazgatói, igazgatóhelyettesi szerepkör és a tantestületi légkör, míg 2014-re csak a tantestületi légkör markáns hatása maradt meg a modellekben. Érdemes kiemelni, hogy mindhárom évben a tantestületi légkör hatása a legerősebb, továbbá azt is, hogy mind a három modell a szignifikáns magyarázó változók számától függetlenül közepesen erős, 22-25\%-os magyarázó erővel bír (3. táblázat).

3. táblázat: A vezető iránti bizalom (igazságos, beosztottakat bevonó) becslésére létrehozott regressziós modellek összefoglalása $\left(\beta\right.$, korrigált $\left.R^{2}\right)$

\begin{tabular}{lrrr}
\hline & 2004 & 2009 & 2014 \\
\hline Pedagóguspályán eltöltött idő (év) & 0,166 & & \\
Igazgató vagy igazgatóhelyettes & 0,175 & 0,211 & \\
Pedagógusok száma & $-0,097$ & & \\
Régió: Közép-Dunántúl (Ref. Budapest) & $-0,086$ & & \\
\hline Tantestületi légkör (fökomponens) & 0,388 & 0,445 & 0,426 \\
Korrigált $R^{2}$ & 0,251 & 0,248 & 0,221 \\
A modell szignifikanciája $(p)$ & $<0,001$ & $<0,001$ & $<0,001$ \\
\hline
\end{tabular}

Megjegyzés: A táblázatban az Enter módszerrel épített modellekbe vitt összesen 31 elemü változószettből csak azok a független változók szerepelnek, melyek valamelyik modellben szignifikáns $(p<0,05)$ szerepet kaptak. A mindhárom évben megjelenő magyarázó változókat szürke színezéssel emeltük ki a táblázatban.

A kizárólag individuális jellemzőket tartalmazó modellek magyarázóereje alacsony, a korrigált $R^{2}$ értékei 0,014 és 0,111 között mozognak. 
A munkatársak iránti bizalom elemei kapcsán is szignifikáns modelleket kaptunk $(p<0,001)$, melyek közül a Kölcsönös munkatársi törődés magyarázatára épülő modellek magyarázóereje a legerősebb $\left(R^{2}{ }_{2004}=0,240, R^{2}{ }_{2009}=0,209, R_{2014}^{2}=0,256\right)$, melyektől némiképp gyengébb, s az évek múltával csökkenő a munkatársak visszaélésének hiányát magyarázó modelleké $\left(R_{2004}^{2}=0,234, R^{2}{ }_{2009}=0,168, R_{2014}^{2}=0,164\right)$, és a leggyengébb, ugyanakkor az évek során növekvő a munkatársi morál magyarázatára irányuló modelleké $\left(R^{2}{ }_{2004}=0,087, R^{2}{ }_{2009}=0,122, R^{2}{ }_{2014}=0,154\right)$. A munkatársi kapcsolatok szakmai és ezen belül érzelmi, kapcsolati oldalát megjelenítő Kölcsönös munkatársi törödés, valamint a munkatársi kapcsolatokban a munkavégzés, illetve érzelmi-kapcsolati szinten megbízhatóságra, jóindulatra utaló Munkatársi visszaélés biánya alskálákra egyértelmüen a tantestületi légkörnek van a legerősebb hatása: mind a három év tekintetében kijelenthető, hogy a légkörmutató értékének növekedése jelentősen növeli a pedagógusok bizalomérzetét. A munkatársi morált viszont - feltehetően vezetői szerepükből is adódóan - elsősorban az iskolavezetés tagjai (igazgatók, igazgatóhelyettesek) vonják leginkább kétségbe, ezen egyéni jellemző mindhárom évben jelentős hatást gyakorol e téren a bizalomra. Az éves szintű modellek hasonlóságai mellett kiemelendők a 2014-re épített modellek másik két évhez képest mutatkozó eltérései is: 2014-re a munkatársi bizalom becslésére létrehozott modellekben megjelent a fenntartó befolyásoló szerepe. Az állami iskolákhoz képest a magán, illetve egyéb fenntartású iskolákban dolgozó pedagógusok inkább tapasztaltak munkatársi visszaéléseket a szervezetükben, az egyházi iskolákban pedig sokkal inkább felmerültek a munkamorállal kapcsolatos kétségek. 2014-ben a Munkatársi munkamorál kétségének magyarázatára épített modellben egyértelmübbé vált az iskolák fővároshoz viszonyított regionális elhelyezkedésének hatása is - mely a fóvárosi iskolákban dolgozó pedagógusok nagyobb mértékü bizalomhiányát mutatja (4. táblázat).

4. táblázat: A munkatársak iránti bizalom becslésére létrehozott regressziós modellek összefoglalása $\left(\beta\right.$, korrigált $\left.R^{2}\right)$

\begin{tabular}{|c|c|c|c|c|c|c|}
\hline & \multicolumn{3}{|c|}{ Kölcsönös munkatársi törődés } & \multicolumn{3}{|c|}{ Munkatársi visszaélés hiánya } \\
\hline & 2004 & 2009 & 2014 & 2004 & 2009 & 2014 \\
\hline Igazgató vagy igazgatóhelyettes & 0,138 & 0,231 & & 0,112 & 0,170 & \\
\hline $\begin{array}{l}\text { Milyen feladatokat lát el: } \\
\text { osztályfönök }\end{array}$ & & & & $-0,080$ & & \\
\hline $\begin{array}{l}\text { Milyen feladatokat lát el: } \\
\text { tagozatfelelős, munkaközösség- } \\
\text { vezető }\end{array}$ & & & 0,131 & & & \\
\hline Pedagógusok száma & $-0,111$ & & & & & \\
\hline Régió: Közép-Magyarország & & 0,106 & & & 0,104 & \\
\hline Régió: Közép-Dunántúl & $-0,092$ & 0,098 & & $-0,085$ & 0,106 & \\
\hline Régió: Nyugat-Dunántúl & & & & & & 0,177 \\
\hline Régió: Észak-Magyarország & & 0,117 & & & & 0,204 \\
\hline
\end{tabular}


4. táblázat: (folyt.)

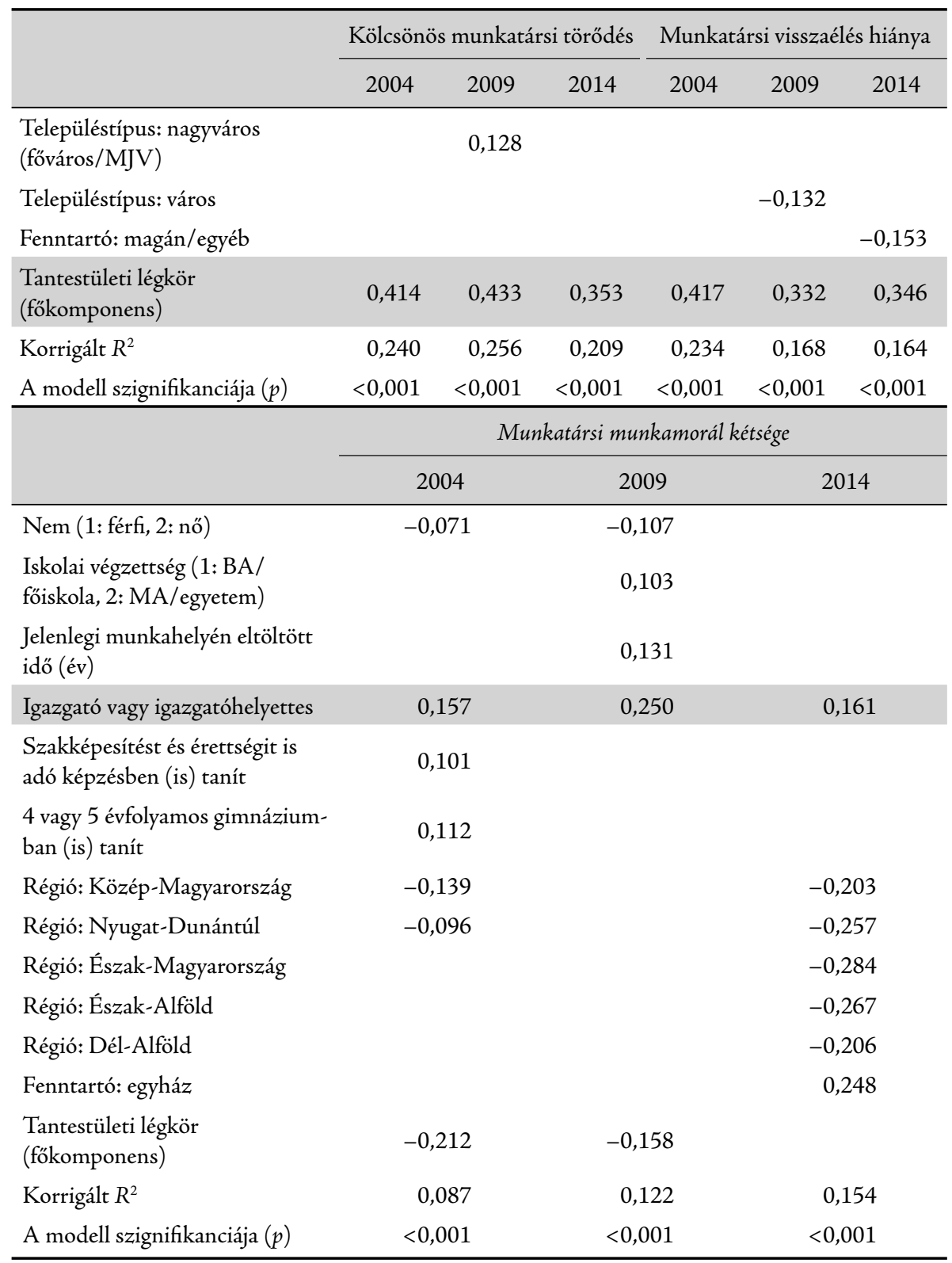

Megjegyzés: A táblázatban az Enter módszerrel épített modellekbe vitt, összesen 31 elemü változószettből csak azok a független változók szerepelnek, melyek valamelyik modellben szignifikáns $(p<0,05)$ szerepet kaptak. Referenciakategóriák: régió esetén Budapest, településtípus esetén község, fenntartó esetén állami/önkormányzati fenntartás. A táblázatban dőlten jelzett alskálák esetében a magasabb értékek bizalmatlanságot jelölnek. A mindhárom évben megjelenő magyarázó változókat szürke színezéssel emeltük ki a táblázatban. 


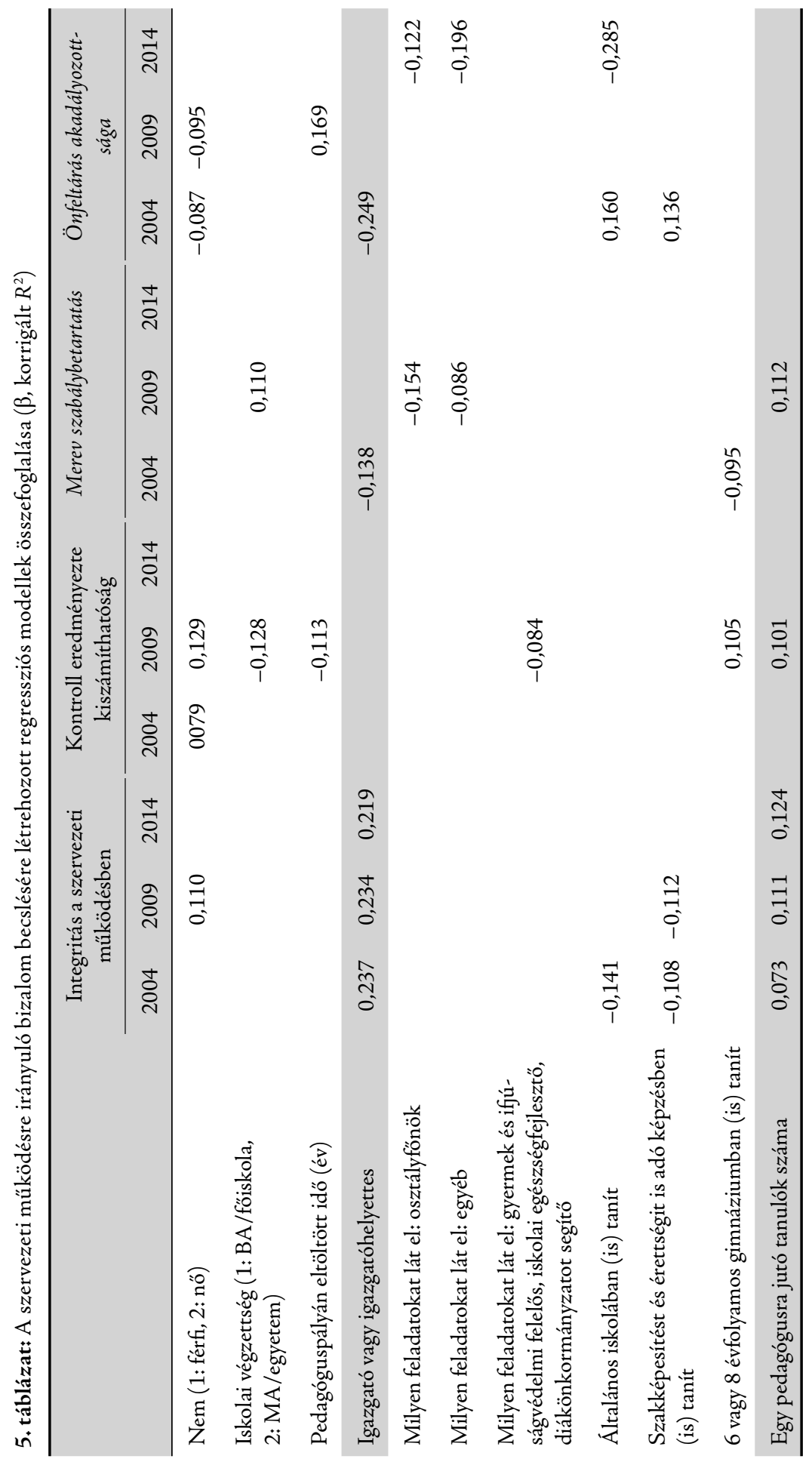




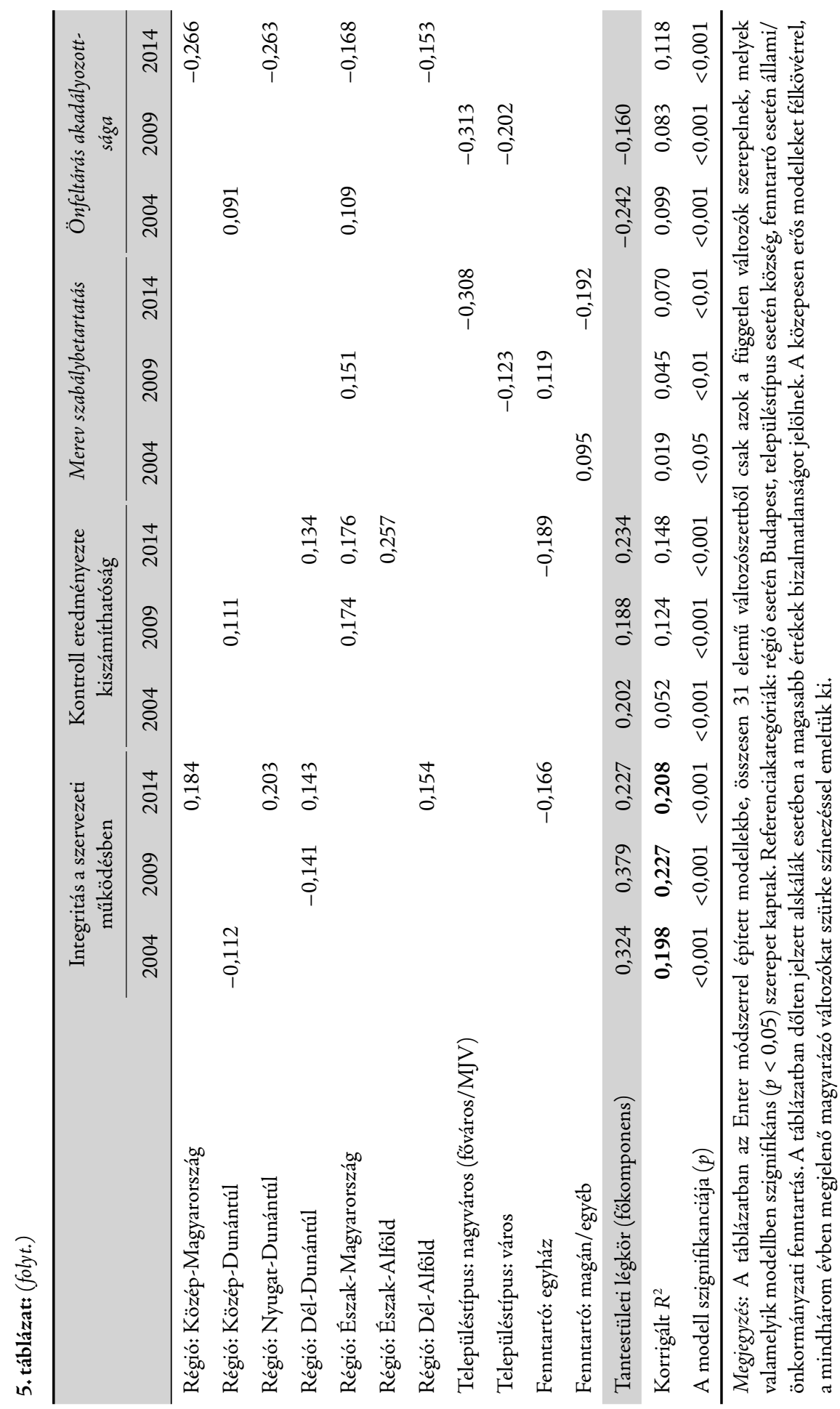


A szervezeti működésre irányuló bizalom becslésére létrehozott szignifikáns regreszsziós modellek közül csak egy, a kiszámíthatóságra, az elfogadott szabályoknak megfelelő müködésre, valamint a bizalommal való visszaélés hiányára utaló Integritás a szervezeti működésben alskála esetében rajzolódott ki mindhárom évre közepesen erős modell $\left(R^{2}{ }_{2004}=0,198, R^{2}{ }_{2009}=0,227, R_{2014}^{2}=0,208\right)$. A másik három dimenzió estében a modellek magyarázóereje inkább gyenge (10-15\%-os) vagy kifejezetten gyenge (10\% alatti). Utóbbi modellek esetén a kapott eredmények fenntartásokkal kezelendők, hozzátéve, hogy a magyarázóerő ezen modellek esetében az évek előrehaladtával növekvő tendenciát mutat, ami azt jelzi, hogy a rendelkezésünkre álló változószettel a szervezeti müködésre vonatkozó bizalom varianciájának egyre nagyobb hányadát sikerült megragadnunk. $\mathrm{A} z$ Integritás a szervezeti müködésben dimenzió megítélésében mindhárom évben markáns pozitív szerepet kap a tantestület oldottságát, haladóbb szellemiségét, nagyvonalúságát, rugalmasságát, ösztönzőbb jellegét együttesen mérő légkörmutató, valamint a vezetői beosztás. Emellett kisebb, de egyre erősödő hatással folyamatosan jelen van az egy pedagógusra jutó tanulók száma is, melynek magyarázata abban kereshető, hogy az egy főre jutó nagyobb tanulólétszám növelheti a szakmai, pedagógiai, módszertani kihívásokat. A tantestületi légkör erőteljes hatása a Kontroll eredményezte kiszámíthatóság esetében is megmutatkozik. A másik két dimenzió (Merev szabálybetartatás, Önfeltárás akadályozottsága) kapcsán - mely esetekben csak igen gyenge modelleket sikerült létrehozni - nincs olyan tényező, melynek hatása mindegyik vizsgált évben szignifikánsan megjelenne. A szervezeti működéssel kapcsolatos bizalmat vizsgáló 2014. évi modellekben a bizalmat szignifikánsan befolyásoló tényezők közt szintén megjelent a fenntartó: az állami fenntartású iskolákhoz képest a magán-, illetve egyéb fenntartású iskolákban dolgozó pedagógusok bizalma magasabb (mely a merev szabálybetartatás gyengébb érvényesülésében érhető tetten), míg az egyházi iskolákban alacsonyabb (mely a integritás csökkenésében, valamint a kontroll eredményezte kiszámíthatóság felől a merev szabálytartatás felé történő elmozdulásban ölt testet) (5. táblázat).

Mint korábban is utaltunk rá, a megkérdezett pedagógusok mindhárom adatfelvétel esetén leginkább a szakmaiság szervezeten belüli meglétével értettek egyet, vagyis azzal, hogy az iskolájukban szakmailag magasan kvalifikált és elkötelezett kollégákkal dolgoznak együtt, továbbá a munkavégzés során szakmai kihívásokat jelentő feladatokat kapnak, és biztosítottak a szakmai fejlődési lehetőségek is. Az eddigi eredményeinkhez hasonlóan az iskolák szakmaiságának pedagógusaik általi megítélését szintén erősen befolyásolja a tantestületen belül kialakult légkör minősége: a légkörindex növekedésével - a modellben szereplő többi magyarázó változó hatásának kontroll alatt tartása mellett - erőteljesen nő a szervezeten belüli szakmaiság érzete. 2004-ben a szervezet szakmai kompetenciaorientáltságának becslésére felállított, közepesen erős magyarázó erővel bíró lineáris modellt egyértelműen az iskola légköre dominálja. Emellett az iskola regionális elhelyezkedése, valamint a pedagógusok egyéni jellemzői (nem, pályán eltöltött évek, iskolavezetői szerep, érettségit nem adó szakképzésben folytatott oktatói tevékenység) is befolyásolták a szervezeten belüli szakmaisággal kapcsolatos bizalmat. 2009-ben azonban - némiképp alacsonyabb magyarázóerővel - a tantestületi légkör mellett a fővároshoz képesti regionális elhelyezkedés hatásának dominanciája is tapasztalható, azaz a vidéki iskolákban rendre magasabb a szervezet szakmaiságával mért bizalom szintje, mint a fóvárosi iskolákban. Ezeken túl még az egy pedagógusra jutó tanulók számának növekedése emelte a szervezeti bizalom értékét. A 2014. évi modellben a tantestületi légkör 
hatása még erősebbé vált. További érdekes eredmény, hogy az állami iskolákban dolgozó pedagógusokhoz képest az egyházi fenntartású iskolákban szignifikánsan kisebb értékek mérhetők (6. táblázat).

6. táblázat: A szervezeten belüli szakmaiságra vonatkozó bizalom (szakmai kompetenciaorientáltság) becslésére létrehozott regressziós modellek összefoglalása $\left(\beta\right.$, korrigált $\left.R^{2}\right)$

\begin{tabular}{lccc}
\hline & 2004 & 2009 & 2014 \\
\hline Nem (1: férfi, 2: nő) & 0,111 & & \\
Pedagóguspályán eltöltött idő (év) & 0,111 & & \\
Igazgató vagy igazgatóhelyettes & 0,179 & & \\
Szakképesítést igen, de érettségit nem adó & $-0,105$ & & \\
képzésben (is) tanít & & & \\
Egy pedagógusra jutó tanulók száma & & 0,111 & \\
Régió: Közép-Magyarország & & 0,111 & \\
Régió: Közép-Dunántúl & & 0,142 & \\
Régió: Dél-Dunántúl & & 0,177 & \\
Régió: Észak-Magyarország & & 0,200 & \\
Régió: Észak-Alföld & 0,110 & 0,170 & \\
Régió: Dél-Alföld & & 0,224 & \\
Településtípus: nagyváros (föváros/MJV) & 0,141 & & 0,188 \\
Településtípus: város & 0,151 & & 0,447 \\
Fenntartó: egyház & & 0,222 \\
Tantestületi légkör (fökomponens) & 0,331 & 0,343 & $<0,001$ \\
\hline Korrigált $R^{2}$ & 0,224 & 0,159 & \\
A modell szignifikanciája (p) & $<0,001$ & $<0,001$ & \\
\hline & & & \\
\hline
\end{tabular}

Megjegyzés: A táblázatban az Enter módszerrel épített modellekbe vitt, összesen 31 elemü változószettből csak azok a független változók szerepelnek, melyek valamelyik modellben szignifikáns $(p<0,05)$ szerepet kaptak. Referenciakategóriák: régió esetén Budapest, településtípus esetén község, fenntartó esetén állami/önkormányzati fenntartás. A mindhárom évben megjelenő magyarázó változókat szürke színezéssel emeltük ki a táblázatban.

\section{Következtetések}

Tanulmányunkban három pedagógus-adatfelvétel alapján lineáris regressziós modellek segítségével vizsgáltuk a gyakorló pedagógusok szervezeti bizalommal kapcsolatos személyes percepcióit, a vezetők és munkatársak iránti, illetve a szervezet müködésével, szakmaiságával kapcsolatos bizalom különböző dimenzióinak alakulását, valamint az azokra ható releváns tényezőket. 
Eredményeink szerint a pedagógusok mindhárom adatfelvétel esetén iskolájuk szakmaiságát értékelték átlagosan a legmagasabbra, amit a kontroll eredményezte kiszámítható szervezeti müködést, a munkatársak kölcsönös törődését, az iskolavezető megítélését, illetve a munkatársi visszaélés hiányát jelző bizalomdimenziók követtek. Az adatok alapján az is kijelenthető, hogy a bizalomhiányra utaló dimenziók közül az iskola merev szabálybetartása sokkal inkább jellemző, mint a nem megfelelő munkatársi munkamorál vagy az önfeltárást akadályozó magas szintü érzelmi alapú bizalom hiánya.

Az eredmények azt is jelzik, hogy a vizsgált 10 éves időszak nem egységes az iskolákban érvényesülő bizalom mértéke tekintetében, és a változások nem írhatók le egy lineáris javulási vagy romlási folyamatként. 2004-hez képest 2009-ben a vizsgált kilenc szervezeti bizalom dimenzióban a munkatársi munkamorál kétségét, illetve a szervezeti integritást jelző alskálák kivételével - melyek esetében stagnálás tapasztalható - nőttek az átlagértékek. Ezt követően 2014-ben viszont jelentős bizalomcsökkenés következett be, s a bizalom szintje visszaállt a 2004-es szintre. Sőt, 2004-hez képest 2014-re jelentősen csökkent az elfogadott szabályoknak megfelelő müködést jelző szervezeti integritás értéke. Elmondható továbbá, hogy 2014-ben fennmaradtak a negatív dimenziókban megindult kedvezötlen tendenciák is.

A 2004. évi adatfelvételre épülő modellekben még számos egyéni jellemző (nem, iskolai végzettség, pályán eltöltött évek száma stb.) is hatást gyakorolt a pedagógusok szervezeti bizalommal kapcsolatos percepciójára, ugyanakkor 2014-re ezen tényezők hatásai szinte teljes mértékben eltüntek, s szerepüket a formális és informális szervezeti jellemzők vették át. További különbség, hogy a 2014-es modellekben egyértelmübbé vált az iskolák fövároshoz viszonyított regionális elhelyezkedésének hatása (ami általában a fóvárosi iskolákban dolgozó pedagógusok bizalomhiányát jelzi), valamint a befolyásoló tényezők között megjelent a fenntartó is. Utóbbi kapcsán általánosságban kijelenthető az egyházi iskolák bizalomdeficite, mely a munkamorállal kapcsolatos kétségek növekedésében, a szervezeti integritás csökkenésében, a kontroll eredményezte kiszámíthatóság felől a merev szabálytartatás felé történő elmozdulásban, valamint a szervezeten belüli szakmaiságra vonatkozó bizalom csökkenésében ölt testet. Mivel a korábbi években nem volt meghatározó a fenntartó szerepe, ezért ezek az eredmények utalhatnak arra is, hogy a 2010-es évektől az iskolák egyre szélesebb körét érintő fenntartóváltások bizonytalanságot, bizalmatlanságot okoztak, és a szervezetek (illetve fenntartók) szakmaiságával kapcsolatos kételyeket ébresztettek a pedagógusokban.

A szervezeti bizalom elemeinek vizsgálatai egyértelműen kimutatták a tantestületen belüli légkörbizalomra gyakorolt nagymértékủ hatásait. Eredményeink szerint minél magasabb a tantestület oldottságát, haladóbb szellemiségét, nagyvonalúságát, rugalmasságát, ösztönzőbb jellegét együttesen mérő légkörmutató értéke, annál erősebb a pedagógusok vezetők, munkatársak iránti, illetve a szervezet müködésével, szakmaiságával kapcsolatos bizalomérzet. Főként az oldottabb, ösztönzőbb tantestületi légkör hat pozitívan a szervezeti bizalom egyes elemeire.

\section{IRODALOM}

Bourdieu, P. (1997) Gazdasági tőke, kulturális tőke, társadalmi tőke. In: ANGelusz R. (ed.) A társadalmi rétegződés komponensei. Budapest, Új Mandátum Kiadó. pp. 156-177. 
- SZÉLL KRISZTIÁN - FEHÉRVÁRI ANIKÓ - PAKSI BORBÁLA: PEDAGÓGUSOK, ISKOLA, BIZALOM -

Bryk, A. S. \& Schneider, B. (2002) Trust in Schools: A Core Resource for Improvement. New York, Russell Sage Foundation.

Bryk, A. S., Sebring, P. B., Allensworth, E., Luppescu, S. \& Easton, J. Q. (2010) Organizing Schools for Improvement: Lessons from Chicago. Chicago, The University of Chicago Press.

Coleman, J. S. (1988) Social Capital in the Creation of Human Capital. American Journal of Sociology, Vol. 94. pp. 95-120. DOI: 10.1086/228943

Fullan, M. (2010) All Systems Go: The Change Imperative for Whole System Reform. California, Corwin, Thousand Oaks.

Fullan, M. (2011) Choosing the Wrong Drivers for Whole System Reform. Melbourne, Centre for Strategic Education. https://edsource.org/wp-content/uploads/old/Fullan-WrongDrivers11.pdf [Letöltve: 2019. 01. 23.]

Handford, C. V. \& Leithwood, K. (2013) Why Teachers Trust School Leaders. Journal of Educational Administration, Vol. 51. No. 2. pp. 194-212.

Hargreaves, A. \& Fullan, M. (2012) Professional Capital: Transforming Teaching in Every School. New York, Teachers College Press.

Harris, J., Caldwell, B. \& Longmuir, F. (2013) Literature Review: A Culture of Trust Enhances Performance. Melbourne, Australian Institute for Teaching and School Leadership. https://www.aitsl.edu.au/docs/default-source/default-documentlibrary/insights---literature-review---a-culture-of-trust-enhances-performance. pdf?sfvrsn=6862e83c_0 [Letöltve: 2019. 01.23.]

Hunyadi L. (2000) A determinációs együtthatóról. Statisztikai Szemle, Vol. 78. No. 9. pp. 753-765.

Kopp E. (2016) A pedagógusok által érzékelt iskolai kultúraelemek és kapcsolatuk a szervezeti szocializációval. In: VÁmos Á. (ed.) Tanuló pedagógusok és az iskola szakmai tôkéje. Budapest, ELTE Eötvös Kiadó. pp. 57-78.

PAKSI B. (2011) A kötetben bemutatott kutatási eredmények módszertani háttere. In: Paksi B. \& Demetrovics Zs. (eds) Drogprevenció és egészééfejlesztés az iskolában. NDI. Budapest, L'Harmattan. pp. 95-170.

Paksi B., Felvinczi K. \& Schmidt A. (2004) Prevenciós / egészségfejlesztési tevékenység a közoktatásban. Kutatási beszámoló. http://www.nefmi.gov.hu/2005/prevenciostevekenyseg [Letöltve: 2019. 01. 23.]

Paksı B. \& Sснмidt A. (2006) Pedagógusok mentálhigiénés állapota: Különös tekintettel az iskolai értékátadást, egészségfejlesztést és problémakezelést befolyásoló dimenziókra. Új Pedagógiai Szemle, Vol. 56. No. 6. pp. 48-64.

Paksi B., Veroszta Zs., Schmidt A., Magi A., Vörös A. \& Felvinczi K. (2015) Pedagógus - pálya - motiváció: Kutatási tapasztalatok a pályamotiváció és a lelki egészség vizsgálata alapján (I. és II. kötet). Budapest, Oktatási Hivatal.

SAss J. (2005) Bizalommintázatok és bizalmi döntések a szervezetekben. Pécs, PhD-értekezés. 


\section{MELLÉKLET}

1. melléklet: Az elemzéshez használt adatfelvételek (adatbázisok) főbb módszertani jellemzői

\begin{tabular}{|c|c|c|c|}
\hline Adatfelvétel & $\begin{array}{l}\text { 2004. tavasza } \\
\text { (Paksi-Felvinczi- } \\
\text { Schmidt 2004) }\end{array}$ & $\begin{array}{l}\text { 2009. tavasza } \\
\text { (Paksi 2011) }\end{array}$ & $\begin{array}{l}\text { 2014. tavasza } \\
\text { (Paksi et al. 2015) }\end{array}$ \\
\hline Célpopuláció & $\begin{array}{l}\text { közoktatási intézmé- } \\
\text { nyekben (általános } \\
\text { iskolákban, középisko- } \\
\text { lákban) tanító fóállású } \\
\text { pedagógusok }\end{array}$ & $\begin{array}{l}\text { közoktatási intézmé- } \\
\text { nyekben (általános } \\
\text { iskolákban, középisko- } \\
\text { lákban) tanító fókállású } \\
\text { pedagógusok }\end{array}$ & $\begin{array}{l}\text { közoktatási intézmé- } \\
\text { nyekben (óvodákban, } \\
\text { általános iskolákban, } \\
\text { középiskolákban, } \\
\text { kollégiumokban, } \\
\text { szakszolgáltatóknál) } \\
\text { fö munkaviszony } \\
\text { keretében, pedagógus } \\
\text { munkakörben alkalma- } \\
\text { zott pedagógusok }\end{array}$ \\
\hline Területi lefedettség & országos & országos & országos \\
\hline Mintaválasztás módja & $\begin{array}{l}\text { Kétlépcsős, rétegzett } \\
\text { véletlen mintavétel: } \\
\text { 1. Intézményi minta: } \\
\text { székhely (Budapest- } \\
\text { vidék), programtípus } \\
\text { és tantestület mérete } \\
\text { szerint } \\
\text { 2. Pedagógusminta: } \\
\text { mintába került } \\
\text { intézményekben } \\
\text { korcsoport szerint }\end{array}$ & $\begin{array}{l}\text { Kétlépcsős, rétegzett } \\
\text { véletlen mintavétel: } \\
\text { 1. Intézményi minta: } \\
\text { székhely (Budapest- } \\
\text { vidék) és programtí- } \\
\text { pus szerint } \\
\text { 2. Pedagógusminta: } \\
\text { mintába került } \\
\text { intézményekben } \\
\text { feladatellátási helyek } \\
\text { típusa és mérete } \\
\text { szerint }\end{array}$ & $\begin{array}{l}\text { Kétlépcsős, rétegzett } \\
\text { véletlen mintavétel: } \\
\text { 1. Feladatellátási hely } \\
\text { minta: területi elhe- } \\
\text { lyezkedés, fenntartó } \\
\text { és feladatellátási hely } \\
\text { típusa szerint } \\
\text { 2. Pedagógus minta: } \\
\text { arányos egyszerü } \\
\text { véletlen mintavétel }\end{array}$ \\
\hline $\begin{array}{l}\text { Elemzéshez használt } \\
\text { nettó mintanagyság }\end{array}$ & 264 iskola; 1020 fó & $\begin{array}{l}165 \text { feladatellátási } \\
\text { hely; } 692 \text { fó }\end{array}$ & $\begin{array}{l}141 \text { feladatellátási } \\
\text { hely; } 852 \text { fö }\end{array}$ \\
\hline Elméleti hibahatár & $\begin{array}{l}95,5 \% \text {-os megbízható- } \\
\text { sági szinten } \pm 3,2 \%\end{array}$ & $\begin{array}{l}95,5 \% \text {-os megbízható- } \\
\text { sági szinten } \pm 3,8 \%\end{array}$ & $\begin{array}{l}95 \% \text {-os megbízhatósá- } \\
\text { gi szinten } \pm 3,4 \%\end{array}$ \\
\hline Adatgyüjtési eljárás & \multicolumn{3}{|c|}{$\begin{array}{l}\text { kevert technika: kérdezőbiztosok bevonásával, iskolai színtéren, sze- } \\
\text { mélyes megkereséssel zajló kérdezés, face to face és önkitöltős módszer } \\
\text { kombinálásával }\end{array}$} \\
\hline Súlyozás & \multicolumn{3}{|c|}{ rétegkategóriák szerinti mátrix súlyozás } \\
\hline Felhasznált adatok & \multicolumn{3}{|c|}{$\begin{array}{l}\text { szervezeti bizalom, tantestületen belüli légkör, szervezet formális jellem- } \\
\text { zői, pedagógusok egyéni jellemzői }\end{array}$} \\
\hline
\end{tabular}


2. melléklet: A lineáris regressziós modellek magyarázó változói

\begin{tabular}{|c|c|c|}
\hline Bevo & nt magyarázó változók & Változóértékek \\
\hline \multicolumn{3}{|c|}{ Pedagógusok egyéni jellemzői } \\
\hline & A kérdezett neme & 1: férfi / 2: nő \\
\hline 2. & A kérdezett legmagasabb képzettségi szintje & $\begin{array}{l}\text { 1: BA/BSC/föiskola } \\
\text { 2: MA/MSC/egyetem }\end{array}$ \\
\hline & Hány évet töltött folyamatosan a pedagóguspályán? & folytonos változó \\
\hline 4. & Hány éve dolgozik a jelenlegi munkahelyén? & folytonos változó \\
\hline 5. & Igazgató vagy igazgatóhelyettes & $0:$ nem / 1: igen \\
\hline & $\begin{array}{l}\text { Jelenlegi iskolájában milyen feladatokat lát el: tagozatfelelős, } \\
\text { munkaközösség vezető }\end{array}$ & $0:$ nem / 1: igen \\
\hline 7. & Jelenlegi iskolájában milyen feladatokat lát el: osztályfönök? & $0:$ nem / 1: igen \\
\hline & $\begin{array}{l}\text { Jelenlegi iskolájában milyen feladatokat lát el: gyermek- és ifjú- } \\
\text { ságvédelmi felelős, iskolai egészségfejlesztő, diákönkormányzatot } \\
\text { segitő }\end{array}$ & $0:$ nem / 1: igen \\
\hline & Jelenlegi iskolájában milyen feladatokat lát el: egyéb & $0:$ nem / 1: igen \\
\hline 10. & Milyen képzési típusban (is) tanít: általános iskola & $0:$ nem / 1: igen \\
\hline & Milyen képzési típusban (is) tanít: 6 vagy 8 évfolyamos gimnázium & $0:$ nem / 1: igen \\
\hline & Milyen képzési típusban (is) tanít: 4 vagy 5 évfolyamos gimnázium & $0:$ nem / 1: igen \\
\hline & $\begin{array}{l}\text { Milyen képzési típusban (is) tanít: szakképesítést és érettségit is } \\
\text { adó képzés }\end{array}$ & $0:$ nem / 1: igen \\
\hline & $\begin{array}{l}\text { Milyen képzési típusban (is) tanít: szakképesítést igen, de érettsé- } \\
\text { git nem adó képzés }\end{array}$ & $0:$ nem / 1: igen \\
\hline
\end{tabular}

\section{Iskola formális és informális jellemzői}

15. Fő munkaviszony keretében, pedagógus-munkakörben alkalmazott pedagógusok száma

folytonos változó

16. Egy pedagógusra jutó tanulók száma

folytonos változó

17. Régió: Budapest (Ref.)

$0:$ nem / 1: igen

18. Régió: Pest megye (fóváros nélkül)

$0:$ nem / 1: igen

19. Régió: Közép-Dunántúl

$0:$ nem / 1: igen

20. Régió: Nyugat-Dunántúl

$0:$ nem / 1: igen

21. Régió: Dél-Dunántúl

0: nem / 1: igen

22. Régió: Észak-Magyarország

$0:$ nem / 1: igen

23. Régió: Észak-Alföld

0 : nem / 1: igen

24. Régió: Dél-Alföld

$0:$ nem / 1: igen

25. Településtípus: nagyváros (főváros/MJV)

$0:$ nem / 1: igen

26. Településtípus: egyéb város

$0:$ nem / 1: igen

27. Településtípus: nagyközség/község (Ref.)

0: nem / 1: igen 
2. melléklet: (folyt.)

\begin{tabular}{ll}
\hline Bevont magyarázó változók & \multicolumn{1}{c}{ Változóértékek } \\
\hline 28. Fenntartó: állami/önkormányzati (Ref.) & $0:$ nem / 1: igen \\
29. Fenntartó: egyházi & $0:$ nem / 1: igen \\
30. Fenntartó: magán/egyéb & $0:$ nem / 1: igen \\
31. Tantestületen belüli légkör: feszüllt-oldott & átlagként aggregált \\
32. Tantestületen belüli légkör: kevéssé innovatív-haladó szellemü & folytonos változó \\
& átlagként aggregált \\
33. Tantestületen belüli légkör: kicsinyes-nagyvonalúltozó & átlagként aggregált \\
34. Tantestületen belüli légkör: merev-rugalmas & folytonos változó \\
& átlagként aggregált \\
35. Tantestületen belüli légkör: visszabúzó-ösztönzö & folytonos változó \\
\hline
\end{tabular}

\begin{tabular}{lll}
\hline \multicolumn{3}{c}{ Adatfelvétel éve } \\
\hline 36. & $E_{v}: 2004$ (Ref.) & $0:$ nem / 1: igen \\
37. & Év: 2009 & $0:$ nem / 1: igen \\
38. & Év: 2014 & $0:$ nem / 1: igen \\
\hline 31. Tantestületen belüli légkör (fökomponens) & folytonos változó \\
\hline
\end{tabular}

A cikk a Creative Commons Attribution 4.0 International License (https://creativecommons.org/licenses/ by/4.0/) feltételei szerint publikált Open Access közlemény, melynek szellemében a cikk bármilyen médiumban szabadon felhasználható, megosztható és újraközölhető, feltéve, hogy az eredeti szerző és a közlés helye, illetve a CC License linkje és az esetlegesen végrehajtott módosítások feltüntetésre kerülnek. (SID_1) 